\title{
Dietary addition of crude form or ethanol extract of brown propolis as nutritional additive on behaviour, productive performance and carcass traits of lambs in feedlot
}

\author{
J.A. da Silva, C.C.B.F. Ítavo', L.C.V. Ítavo, M. da Graça Morais, P.C.G da Silva, \\ K.L.S.M. Ferelli and T.F.F. de Souza Arco \\ Federal University of Mato Grosso do Sul (UFMS) \\ Faculty of Veterinary Medicine and Animal Science (FAMEZ) \\ Av. Senador Filinto Müller 2443, Cidade Universitária, 79070-900 Campo Grande, Braziil
}

KEY WORDS: carcass yield, fatty acid profile, feed conversion efficiency, flavonoids, feed additives

Received: 26 June 2018

Revised: 4 February 2019

Accepted: 14 March 2019

${ }^{1}$ Corresponding author:

e-mail: camila.itavo@ufms.br

\begin{abstract}
This study was aimed to examine the nutritional efficiency of the balanced supply of flavonoids from the crude or ethanol extract of brown propolis on behaviour, productive performance and carcass traits of lambs in feedlot. Twenty four male lambs were divided into 4 groups (6 animals in each) and fed diet supplemented with: crude brown propolis [13 $\mathrm{g} / \mathrm{kg}$ dry matter (DM)], propolis ethanol extract ( $15 \mathrm{ml} / \mathrm{kg} \mathrm{DM})$, sodic monensin $(0.032 \mathrm{~g} / \mathrm{kg} \mathrm{DM})$ - positive control, or diet without any enrichment (negative control). The basic diet was a total mixed ration with roughage:concentrate ratio of 500:500 (w/w). In animals receiving crude propolis $(P<0.05)$ DM intake was higher than in animals fed sodic monensin in the diet. The use of feed additives did not affect feeding behaviour and lambs performance. Carcass yield was lower $(P<0.05)$ in lambs receiving diet with sodic monensin than in lambs fed diets with crude propolis. Also the propolis extract addition into diet decreased carcass yield in comparison to control group. Propolis addition altered the fatty acid profile of meat reducing saturated fatty acid content and increasing unsaturated one in comparison to control group. So, brown propolis supplementation can influence lamb carcass traits and meat quality; however the form of propolis is an important factor. The possible addition of propolis into animal feed can be important from human nutrition point of view.
\end{abstract}

\section{Introduction}

Ionophores - antibiotics used in animal feeding - inhibit gram-positive bacterial growth, provide changes in produced ratio of volatile fatty acids, i.e. increase propionate and decrease methane levels, and enhance energy efficiency of ruminal fermentation (Soltan et al., 2018). However, synthetic antimicrobial agents used as growth promoters in animals can be transferred to the meat consumed by humans and can be a cause of many health risks. Therefore, in 2006 the European Union banned the use of such substances in animal feed (Torres et al., 2010), and so the search for alternative natural compounds is necessary.

Propolis has bacteriostatic activity against grampositive and some gram-negative bacteria (Mirzoeva et al., 1997). It can be an alternative to ionophores used in ruminants (Ítavo et al., 2011a; 2011b) due to the presence of compounds like flavonoids, phenolic acids, esters, phenolic aldehydes and ketones (Funari and Ferro, 2006). The action of propo- 
lis is likely related to changes in the energetic status of the bacterial membrane, which inhibits bacterial motility. However, the chemical composition of propolis depends on the environment and area in which bees are working (Choi et al., 2006). In Brazil, propolis can be classified into three different types: brown, green and red, with brown being interesting for animal nutrition due to the low cost and confirmed in some previous studies satisfactory results (Ítavo et al., 2011a; 2011b).

Some positive results have been observed using the ethanolic extract of propolis in in vitro (Stradiotti Jr. et al., 2004) and in vivo (Ítavo et al., 2011a; 2011b) experiments on ruminants. According to Morsy et al. (2015), the composition of some compounds of propolis collected from different areas (Brazilian red propolis vs Egyptian brown propolis) differed greatly. The ruminal degradation of nutrients in response to both types of propolis was however similar. It could be stated that propolis, independently of the type or site of collection, exerts positive effect on ruminants (Morsy et al., 2015). However, variability of results reported in other studies might be related with methodological differences in animal feeding and lack of proper characterization of propolis (Stelzer et al., 2009), further studies are still needed.

Previously, we have evaluated different forms of propolis (brown or green in crude form, solid residue and alcoholic solution) as an additive to ruminant feed and noted the effect of propolis on the digestibility, feed conversion ratio and performance of ruminants. Ítavo et al. (2011a) concluded that propolis into extract can be potentially used as feed supplement instead of monensin sodium in the diets of feedlot lambs. Ítavo et al. (2011b) found that inclusion of either sodic monensin or brown propolis extract into the diet of feedlot lambs can improve feed efficiency. Although, the inclusion of residues produced during alcoholic extraction of propolis, as a source of flavonoids and phenolic acids with antimicrobial activity, into ruminant diets is feasible (Heimbach et al., 2014; 2016; Gomes et al., 2016), more studies should be carried out to confirm its positive influence on ruminants.

Gomes et al. (2017) evaluated in vitro fermentation characteristics of ruminant diets with ethanol extract of brown propolis as a nutritional additive and found that the degradation and fermentation of diet can be successfully improved by $13 \mathrm{ml} / \mathrm{DM} \mathrm{kg}$ of ethanol extract of propolis containing $14 \mathrm{mg} / \mathrm{ml}$ of flavonoids. Ítavo et al. (2009) found that dietary addition of brown propolis extract does not affect carcass characteristics of feedlot lambs. Likewise, Silva et al.
(2014) tested brown propolis in crude or extract forms as feed supplement for feedlot lambs and observed the same effect on feed intake and digestibility. The results were also comparable to the use of monensin.

We have already compared propolis (alcohol extract, extract residue and even crude form) with monensin as it is a recognized nutritional additive with proven efficacy results for ruminants (Ítavo et al., 2009; 2011a; 2011b; Silva et al., 2014; Heimbach et al., 2014; 2016; Gomes et al., 2016). We have noted that regardless of the form, propolis exerted a positive effect on intake. However, it is understood that the availability and action of the principles can be potentiated by the solubilisation in alcohol (Gomes et al., 2016). Alcohol could be harmful to rumen microorganisms, since it could affect the life of the microbiota (Matthews et al., 2018).

In our previous in vivo and in vitro experiments we have noted positive effects of propolis alcoholic extract, therefore we believe that the use of crude propolis could be also beneficial for animals. Therefore, it was hypothesized that solid crude propolis or alcoholic extract of brown propolis has the potential to replace the sodium monensin as nutritional additive, in association with a high quality diet composed of 500:500 $(\mathrm{w} / \mathrm{w})$ roughage:concentrate ratio for feedlot lamb diets. In the study the effects of dietary addition of brown propolis, as crude propolis or ethanol extract, or monensin (positive control) on the behaviour, production performance, carcass and meat characteristics of lambs in feedlot were evaluated.

\section{Material and methods}

The experiment was carried out at the Faculty of Veterinary Medicine and Animal Science (FAMEZ), Federal University of Mato Grosso do Sul (UFMS) (Brazil). This work has been approved by Ethical Committee for use of animal in experiments (protocol 218/2009).

\section{Propolis characteristics}

Crude brown propolis was collected from Apis mellifera hives in an apiary located at the farm of FAMEZ-UFMS in Terenos, MS (Brazil; $20^{\circ} 26^{\prime} 34.31^{\prime \prime} \mathrm{S}, 54^{\circ} 50^{\prime} 27.86^{\prime} \mathrm{W}$; $530.7 \mathrm{~m}$ altitude). According to Gomes et al. (2017), a nylon mesh screen was placed between the hive body and the cover for production of propolis. After 45 days the screens were removed, packed, transported and kept at $-5^{\circ} \mathrm{C}$ in the Laboratory of Apiculture of FAMEZUFMS. The propolis was produced from flowering plants in the area, mostly Vernonia spp. and Cecropia 
pachystachya as well as Luehea sp., Piptadenia falcata, Tabebuia spp. and Tabebuia caraiba. Crude propolis was mixed with concentrate in milled form and added to the total diet.

Propolis extract was prepared according to Stradiotti Jr. et al. (2004) by infusing $30 \mathrm{~g}$ of crude propolis in $100 \mathrm{ml}$ of $70 \mathrm{v} / \mathrm{v}$ ethanol solution (prepared with grain alcohol, $98^{\circ} \mathrm{GL}$, Ceralcool ${ }^{\circledR}$, São Paulo, Brazil) for 10 days in constant agitation, followed by supernatant removal by filtration through a paper filter $\left(80 \mathrm{~g} / \mathrm{m}^{2}\right.$ with pore size $\left.25 \mu \mathrm{m}\right)$. Crude propolis and propolis extract were kept cool and protected from light.

Crude propolis was milled in a $5-\mathrm{mm}$ mesh screen and analysed for dry matter (DM), ash, methanol-insoluble residues, wax, dry residues (methane-soluble solids), flavonoids and total phenols. Propolis extract was analysed for concentrations of dry residue, flavonoids and phenols content (Table 1).

Table 1. Chemical composition of brown propolis in crude or ethanol extract forms

\begin{tabular}{lr}
\hline Compound & Content \\
\hline Crude propolis & \\
ash, g/kg DM & 34.5 \\
DM, g/kg & 902.9 \\
insoluble in methanol residue, g/kg DM & 585.6 \\
wax, g/kg DM & 95.6 \\
dry residue, g/kg DM & 307.9 \\
phenols, mg/g dry residue & 68.1 \\
flavonoids, mg/g dry residue & 4.6 \\
Propolis extract & \\
dry residue, g/l & 79.5 \\
phenols, mg/g dry residue & 584.9 \\
flavonoids, mg/g dry residue & 15.0 \\
\hline DM - dry matter &
\end{tabular}

The dry residue concentration analysis was carried out according to Funari and Ferro (2006). A 5-ml aliquot of the propolis ethanolic extract, free of wax, was transferred to capsule of dry porcelain (heated in an oven at $105{ }^{\circ} \mathrm{C}$ for $2 \mathrm{~h}$, cooled and then weighted) and the assembly taken to the preheated oven at $105{ }^{\circ} \mathrm{C}$, where it remained for $2 \mathrm{~h}$. After cooling in desiccator, the set was weighed. This analysis was in triplicate and dry residue content (soluble solids in ethanol) was calculated by the ratio of the residue mass deposited in the crucible and the initial mass of crude propolis extracted, corresponding to the aliquot of $5 \mathrm{ml}$.

The flavonoids and total phenols were measured by colorimetry with quercetin and gallic acid as stan- dards, respectively, as described by Funari and Ferro (2006). Total content of polyphenols was measured colorimetrically in an aqueous extract using the Folin-Ciocalteu technique with polyvinylpolypyrrolidone for elimination of interfering substances. Polyphenols were extracted by mixing $1 \mathrm{~g}$ of sample (ground through 1-mm screen) with methanol/water $(90: 10, \mathrm{v} / \mathrm{v})$ and the volume was made up to $100 \mathrm{ml}$. The extracts were then filtered on a $0.22-\mu \mathrm{m}$ PTFE membrane filter (Spritzen, Shanghai, China) in a tube protected from light.

\section{Lambs, experimental design, and diets}

In total, 24 weaned, castrated Texel crossbred lambs (6 month-old, average weight $24.5 \pm 2.9 \mathrm{~kg}$ ) were used in the study. For parasite control, all lambs received a 2-ml intramuscular injection of antibiotic (Coccifin, Ouro Fino Saúde Animal, Ouro Fino, Cravinhos, SP, Brazil) to prevent coccidiosis. Lambs received also an anthelmintic treatment (sodic closantel $10 \mathrm{mg} / \mathrm{kg} \mathrm{BW}$; HIPRA, S.A., Amer (Girona), Spain) upon weaning. Lambs were housed in sheds made from clay tiles, with a ceiling height of $2.5 \mathrm{~m}$ and concrete paving, where they were randomly allotted into individual pens with $3 \mathrm{~m}^{2}(1.5 \mathrm{~m} \times 2 \mathrm{~m})$ each, with wood slat floor, waterer and feed trough.

Animals were randomly assigned to four experimental diets: (1) no additive as negative control; (2) $13 \mathrm{~g} / \mathrm{kg}$ DM of crude brown propolis in solid form (corresponding to $18 \mathrm{mg} / \mathrm{kg} \mathrm{DM}$ of flavonoids); (3) $15 \mathrm{ml} / \mathrm{kg}$ DM (corresponding to $1.2 \mathrm{~g}$ of dry residue and $18 \mathrm{mg} / \mathrm{kg}$ DM of flavonoids) of brown propolis alcoholic extract; and (4) $0.032 \mathrm{~g} / \mathrm{kg}$ DM of sodic monensin (Rumensin ${ }^{\mathrm{TM}}$ Elanco Animal Health, Santo Amaro, SP, Brazil) as positive control in the total mixed diet according to Ítavo et al. (2011a).

The experimental basic diet (Table 2) was formulated to meet the National Research Council requirements for finishing lambs (NRC, 2007) with an average body weight of $20 \mathrm{~kg}$, a potential gain of $200 \mathrm{~g} /$ day and an estimated DM intake of $1 \mathrm{~kg} /$ day. The concentrate was formulated to contain: g/kg: maize meal 517; soybean meal 472 and mineral premix 1 . The mineral premix contained: g/kg: Ca 70, P 48, S 0.75, Na 1.0; mg/kg: Co 0.3, Cu 3.75, I 0.42, Mn 9.00, Se 0.12, Zn 27.0. The same diet was offered with different additives. The additives were included and mixed in the concentrate just before feeding and propolis extract was sprinkled on the concentrate before its mixing with total ration.

The feed was offered twice a day (8:00 and $16: 00)$, to allow nearly $50 \mathrm{~g} / \mathrm{kg}$ of leftovers. Water 
Table 2. Chemical composition of the experimental basic $\operatorname{diet}^{1}$ of feedlot, g/kg DM (unless otherwise stated)

\begin{tabular}{ll}
\hline Chemical composition & $\begin{array}{l}\text { The experimental } \\
\text { basic diet }\end{array}$ \\
\hline DM, g/kg & 910.7 \\
Organic matter & 933.4 \\
Crude protein & 191.7 \\
Neutral detergent fibre & 512.0 \\
Acid detergent fibre & 255.4 \\
Ether extract & 32.2 \\
Total carbohydrates & 709.5 \\
Non-fibre carbohydrates & 197.4
\end{tabular}

DM - dry matter; ${ }^{1}$ basic diet ingredients: $\mathrm{g} / \mathrm{kg}$ : maize meal 517, soybean meal 472, premix mineral 1 with $\mathrm{g} / \mathrm{kg}$ : Ca 70, P 48, S 0.75 , Na 1.0; mg/kg: Co 0.3, Cu 3.75, I 0.42, Mn 9.00, Se 0.12, Zn 27.0; ${ }^{2}$ non-fibrous carbohydrates $=100-($ crude protein + ether extract + neutral detergent fibre + ash)

was provided ad libitum. Tifton 85 (Cynodon spp.) hay was milled to $5 \mathrm{~mm}$ length and used as roughage feed at roughage:concentrate ratio of 500:500 $(\mathrm{w} / \mathrm{w})$ on a DM basis. The amounts of feed offered and refused were weighed daily and registered for each pen to determine DM intake.

The experimental period lasted 67 days and was divided into five periods - the first four of 14 days and the last one of 11 days, until the animals presented slaughter weight (mean of $35 \mathrm{~kg} \mathrm{BW}$ ).

\section{Nutrient intake}

The samples of offered diet and leftovers were dried in a forced ventilation oven at $55^{\circ} \mathrm{C}$ for $96 \mathrm{~h}$ and milled in the 1-mm mesh screen. The determinations of DM, organic matter (OM), crude protein level from total nitrogen (CP) and ether extract (EE), of the diets and the leftovers were performed according to AOAC International (2000), methods 930.15, 942.05, 976.05 and 920.39, respectively. Heat stable $\alpha$-amylase (Termamyl ${ }^{\circledR} 120$; Sigma-Aldrich, St. Louis, MO, USA) was used to determine neutral detergent fibre (NDF) (Mertens, 2002) without sodium sulphite and was expressed inclusive of residual ash. Acid detergent fibre (ADF) was determined by Robertson and Van Soest (1981) method. Total carbohydrates (TCHO) were determined using the equation: 100 - (crude protein + ether extract + ash). To determine non-fibrous carbohydrates (NFC), NDF was subtracted from TCHO.

Nutrient intake (offered nutrient - nutrient of leftovers) and feed conversion (DM intake/weight gain) were evaluated. DM intake (DMI) and NDF intake (NDFI) were evaluated as g/day and body weight percentage $(\mathrm{g} / \mathrm{kg} \mathrm{BW})$.

\section{Ingestive behaviour}

The ingestive behaviour was evaluated every 14 days for a total of four observations. Data collection was performed in sessions beginning at 8:00, at the first daily feeding, and continued for $24 \mathrm{~h}$. The collection of quantitative data on basic behavioural patterns was based on instantaneous scanning and continuous sampling. Therefore, 1-min scans were performed at 10 -min intervals over the $24 \mathrm{~h}$ observation period. A chronological framework was used to record the time the lambs spent feeding, ruminating, resting and moving.

Feeding rate (FR) and rumination rate (RR) of DM and NDF were also obtained in $\mathrm{g} / \mathrm{min}$. To perform this calculation, DMI and NDFI were divided by ingestion time and total rumination time, respectively. Counting the number of chews $\left(\mathrm{NC}_{\mathrm{nb}}\right.$; number/bolus) and time spent of chewing per bolus $\left(\mathrm{TC}_{\mathrm{mb}} ; \mathrm{min} /\right.$ bolus $)$ was performed using a digital stopwatch. To obtain the average number of chews and time spend on chewing each bolus, we observed three boli in three distinct periods $(10: 00-12: 00$, 14:00 - 16:00 and 18:00 - 20:00). The number of daily boli (NDB), the total chewing time (TCT) and number of daily chews (NDC) were obtained.

\section{Productive performance and in vivo body measurements}

The animals were weighed at the beginning of experiment and every 14 days while they were kept in the feedlot until reaching slaughter weight. Both offered diet and leftovers were collected by composite sampling and analysed. Lambs were weighed at the beginning of the study (initial weight) and at the end of the experiment after $16 \mathrm{~h}$ of fasting (slaughter weight; SW). Before slaughter, morphometric measurements $(\mathrm{cm})$ of the lambs standing in natural position were taken using a measuring tape. Body length (BL; base of the tail to the neck), height at withers (HW) and height at rump (HR) (vertical distance from the highest point of these portions to the ground), width at rump (WR), chest girth (CG, behind the shoulders and under the armpits) were measured (Osório et al., 1996a; 1996b). Body compactness (BC) was thereafter calculated with the relationship SW/BL.

\section{Carcass and meat characteristics}

After 67 days, lambs were fasted for $24 \mathrm{~h}$ before they were shipped to a commercial slaughterhouse. Lambs were slaughtered in a slaughter plant $\left(\operatorname{Strut}^{\mathbb{R}}\right)$ in Campo Grande, MS (Brazil). After concussion stunning with captive bolt pistol, using electro narco- 
sis of $220 \mathrm{~V}$ for $10 \mathrm{~s}$, the carotid artery and jugular veins of the lambs were cut for blood drainage. Then carcass skinning and evisceration, decapitation and cut of the distal portion of the limbs were carried out. At the end of slaughter line, all carcasses were weighed to obtain hot carcass weight $(\mathrm{HCW})$, which was used to calculate hot dressing ( $\mathrm{HD}=\mathrm{HCW} /$ $\mathrm{SW} \times 100$ ). After $24 \mathrm{~h}$ cooling at $4{ }^{\circ} \mathrm{C}$, all carcasses were weighed to obtain cold carcass weight $(\mathrm{CCW})$ and cold dressing $(\mathrm{CD}=\mathrm{CCW} / \mathrm{PA} \times 100)$. Cooling losses were also calculated $[\mathrm{CL}=(\mathrm{HCW}-\mathrm{CCW}) /$ $\mathrm{HCW} \times 100]$.

Cold carcasses were measured to obtain internal carcass length (ICL - maximum distance between the inner edge of the pubic bone and anterior edge of the medial portion of the first rib), external carcass length (ECL - distance between the cervicothoracic junction and the first inter-coccygeal joint), rump perimeter (RP - perimeter between the two femoral heads) and thorax depth (TD - maximal distance from sternum bone to withers), as described by Osório et al. (1996a; 1996b). Carcass compactness (CC) was calculated from the CCW/ICL relationship.

Following slaughter standard processing, the carcasses were cut into leg, shoulder, rib, rack, loin and neck. The carcass cuts were weighed and their relation to $\mathrm{CCW}$ was calculated.

Tracing transverse transparent sections between the Longissimus thoracis muscle, between the vertebrae $11^{\text {st }}$ and $13^{\text {th }}$, Longissimus muscle area (LMA) was calculated using the software AUTOCAD ${ }^{\circledR}$ (AUTOCAD $^{\circledR}$ software, Autodesk, Inc., São Rafael, CA, USA). Subcutaneous fat thickness (SFT) was measured in the same sites with a calliper. The Longissimus dorsi muscle was dissected and sectioned between the lumbar vertebrae $11^{\text {st }}$ and $13^{\text {th }}$ for assessment of the proportion of the different carcass tissues (muscle, fat and bone). Muscle samples were used to determinate the chemical composition and meat fatty acid profile.

\section{Fatty acid profile of the Longissimus muscle}

Intramuscular fat from muscle samples was extracted. Freeze-dried samples of meat $(4 \mathrm{~g})$ were homogenized in $25 \mathrm{ml}$ of methanol and $5 \mathrm{ml}$ of chloroform using a tissue homogenizer set at $540 \mathrm{~g}$ (Model Q220 Quimis, Diadema São Paulo, SP, Brazil) for $30 \mathrm{~min}$. The extracts were evaporated under $55^{\circ} \mathrm{C}$ and lipids were stored at $-80{ }^{\circ} \mathrm{C}$ until methylated. Sodium methoxide $(10 \mathrm{ml})$, acetic acid $(1 \mathrm{ml})$ and heptane $(10 \mathrm{ml})$ were added to the mixture prior to a second homogenation carried out for $60 \mathrm{~min}$. Samples were allowed to settle and $2 \mathrm{ml}$ of lipids were collected from the upper heptane phase. Fatty acids were methylated using sodium methoxide in methanol (1:25) as an agent of esterification and methyl acetate $(1 \mathrm{ml})$ plus heptane $(10 \mathrm{ml})$ to minimize saponification. Fatty acid methyl esters were quantified by gas chromatography (model $6890 \mathrm{~N}$ Network 237 GC System, Agilent Technologies, Santa Clara, CA, USA) using a HP-88 capillary column $(100 \mathrm{~m} \times 0.25 \mathrm{~mm}$ i.d., $0.20 \mu \mathrm{m}$ film thickness; Agilent Technologies, Santa Clara, CA, USA).

The injector and detector temperature was $250^{\circ} \mathrm{C}$. Initial column temperature was $120^{\circ} \mathrm{C}(5 \mathrm{~min})$ and it gradually increased $\left(3{ }^{\circ} \mathrm{C} / \mathrm{min}\right)$ to $240{ }^{\circ} \mathrm{C}(15 \mathrm{~min})$. The carrier gas was helium with flow rate $1.5 \mathrm{ml} / \mathrm{min}$. Hydrogen flow to the detector was $35 \mathrm{ml} / \mathrm{min}$, airflow was $450 \mathrm{ml} / \mathrm{min}$, and the flow of $\mathrm{N}_{2}$ make-up gas was $30 \mathrm{ml} / \mathrm{min}$. Identification of fatty acids was done by comparison with the retention times of pure methyl ester standards. Chromatographic standard mixture of fatty acids (C4-C24 Even Carbon Saturated FAMEs; $1000 \mu \mathrm{g} / \mathrm{ml}$ each component in hexane; analytical standard, cat. No. 49453-U; Sigma-Aldrich, St. Louis, MO, USA) was used.

\section{Statistical analysis}

All data were submitted to analysis of variance (ANOVA) using the GLM procedure of SAS Software ver. from 2002 (SAS Institute, Inc., Cary, NC, USA) according to a completely randomized design with four treatments. Since one negative control (treatment without additive) and one positive control (diet with sodic monensin) were considered, the treatments were arranged in completely randomized design with six replications each. The statistical model used was:

$$
\mathrm{Y}_{i j}=\mu+\mathrm{A}_{i}+\varepsilon_{i j}
$$

where: $\mathrm{Y}_{i j}-\mathrm{j}^{\text {th }}$ observation of the additive $i$, $\mu$ - overall constant, $\mathrm{A}_{i}$ - additive effect on diet $i$, with $i=1,2,3$ and 4 , and $\varepsilon_{i j}$ - random error for each $\mathrm{Y}_{i j}$ observation. Main source of variation was nutritional treatment (additive).

Data on carcass measurements were analysed using slaughter weight as covariant. Dry matter intake and the feed:gain ratio were analysed using each lamb as the experimental unit and as well as lamb was the experimental unit for data on performance and carcass. The mean comparisons were accessed using the Tukey's test. Significance was declared at $P \leq 0.05$ and a trend at $0.05<P<0.10$, unless otherwise stated. 


\section{Results}

Nutrient intake (DMI and NDFI, g/day) of animals fed diet supplemented with crude propolis was higher $(P<0.05)$ in comparison to animals receiving diet with sodic monensin. DMI (g/day and $\mathrm{g} / \mathrm{kg} \mathrm{BW})$ and NDFI (g/day and $\mathrm{g} / \mathrm{kg} \mathrm{BW}$ ) were similar for propolis extract treatment and diet without additive (control). Average daily weight gain and feed conversion ratio were not influenced $(P>0.05)$ by additives, with mean values of $163.68 \mathrm{~g} /$ day and 6.57 , respectively (Table 3).

Time spent by feedlot lambs on behavioural activities was not influenced by the additives, with average of 242, 355, 110 and $733 \mathrm{~min} /$ day for feeding, ruminating, moving and resting, respectively (Table 4). The feeding rate $\left(\mathrm{FR}_{\mathrm{DM}}, \mathrm{g} \mathrm{DM} / \mathrm{min}\right)$ was higher $(P<0.05)$ for lambs from the control group $(5.7 \mathrm{~g} / \mathrm{min})$ than for those fed diet with sodic monen$\sin (4.0 \mathrm{~g} / \mathrm{min})$. Other variables of ingestive behaviour (rumination rate, total chewing time, number of daily bolus, number of daily chews, number of chews per bolus, chewing time per bolus) were not affected $(P>0.05)$ by the addition of crude brown propolis, its ethanol extract or sodic monensin into the diets (Table 4).

There were no effect $(P>0.05)$ of additives on the in vivo morphometric measurements (mean values: $\mathrm{BL}=81.14 \mathrm{~cm}, \mathrm{HW}=61.67 \mathrm{~cm}, \mathrm{HR}=$ $60.61 \mathrm{~cm}, \mathrm{WR}=23.11 \mathrm{~cm}, \mathrm{CG}=81.24 \mathrm{~cm}$ and $\mathrm{BC}=0.44 \mathrm{~kg} / \mathrm{cm})($ Table 5$)$. The dietary treatments did not affect $(P>0.05)$ the $\mathrm{RP}(30.0 \mathrm{~cm})$ and $\mathrm{CC}(0.3 \mathrm{~kg} /$ $\mathrm{cm})$ whereas ICL was higher $(P<0.05)$ for lambs fed crude propolis than for those receiving control diet or diet supplemented with propolis ethanol extract (Table 5). The external length (ECL) of the carcass in crude propolis group was higher $(P<0.05)$ than in control one, with no difference $(P>0.05)$ between the propolis extract and sodic monensin groups. The use of crude propolis and sodic monensin increased $(P<0.01)$ thorax depth (TD) in comparison with the lambs fed diet with propolis extract or control one.

Table 3. Effect of diet supplementation with crude brown propolis, propolis ethanol extract and sodic monensin on performance of lambs

\begin{tabular}{lcccccc}
\hline \multirow{2}{*}{ Indices } & \multicolumn{2}{l}{ Treatments } & & \multicolumn{2}{c}{ SEM } & $P$-value \\
\cline { 2 - 5 } & control & $\begin{array}{l}\text { crude } \\
\text { propolis }\end{array}$ & $\begin{array}{l}\text { propolis } \\
\text { extract }\end{array}$ & $\begin{array}{l}\text { sodic } \\
\text { monensin }\end{array}$ & & \\
\hline Initial body weight, $\mathrm{kg}$ & 23.9 & 24.8 & 24.8 & 24.0 & 1.04 & 0.898 \\
Final body weight, $\mathrm{kg}$ & 34.5 & 36.9 & 35.6 & 34.4 & 1.13 & 0.405 \\
Dry matter intake, g/day & $1021.4^{\mathrm{ab}}$ & $1185.1^{\mathrm{a}}$ & $1063.7^{\mathrm{ab}}$ & $943.3^{\mathrm{b}}$ & 43.83 & 0.001 \\
Dry matter intake, g/kg BW & $36.3^{\mathrm{ab}}$ & $40.2^{\mathrm{a}}$ & $36.9^{\mathrm{ab}}$ & $33.7^{\mathrm{b}}$ & 1.24 & 0.001 \\
Neutral detergent fibre intake, g/day & $479.0^{\mathrm{b}}$ & $567.8^{\mathrm{a}}$ & $506.9^{\mathrm{ab}}$ & $457.0^{\mathrm{b}}$ & 21.79 & 0.001 \\
Neutral detergent fibre intake, g/kg BW & $17.0^{\mathrm{ab}}$ & $19.3^{\mathrm{a}}$ & $17.6^{\mathrm{ab}}$ & $16.3^{\mathrm{b}}$ & 0.60 & 0.021 \\
Average daily gain, g/day & 157.6 & 180.5 & 161.1 & 155.6 & 10.72 & 0.366 \\
Feed conversion ratio & 6.5 & 6.6 & 6.6 & 6.1 & 0.35 & 0.735 \\
\hline
\end{tabular}

BW - body weight; SEM - standard error of the mean; ${ }^{1}$ feed conversion ratio = dry matter intake/ weight gain; ${ }^{\text {ab }}$ - means with different superscripts in the same row are statistically different (Tukey's test, $P<0.05$ )

Table 4. Effect of diet supplementation with crude brown propolis, propolis ethanol extract and sodic monensin on ingestive behaviour of lambs

\begin{tabular}{|c|c|c|c|c|c|c|}
\hline \multirow[b]{2}{*}{ Indices } & \multicolumn{4}{|c|}{ Treatments } & \multirow[b]{2}{*}{ SEM } & \multirow[b]{2}{*}{$P$-value } \\
\hline & control & $\begin{array}{l}\text { crude } \\
\text { propolis }\end{array}$ & $\begin{array}{l}\text { propolis } \\
\text { extract }\end{array}$ & $\begin{array}{l}\text { sodic } \\
\text { monensin }\end{array}$ & & \\
\hline Feeding, min/day & 199 & 262 & 239 & 261 & 17.19 & 0.065 \\
\hline Ruminating, min/day & 360 & 360 & 345 & 354 & 17.34 & 0.915 \\
\hline Moving, $\min /$ day & 103 & 122 & 105 & 105 & 12.14 & 0.653 \\
\hline Resting, min/day & 778 & 696 & 751 & 720 & 22.38 & 0.082 \\
\hline Feeding rate, g DM/min & $5.7^{\mathrm{a}}$ & $4.9^{\mathrm{ab}}$ & $4.9^{\mathrm{ab}}$ & $4.0^{\mathrm{b}}$ & 0.39 & 0.041 \\
\hline Rumination rate, g DM/min & 2.8 & 3.3 & 3.2 & 2.6 & 0.27 & 0.298 \\
\hline Rumination rate, g NDF/min & 1.3 & 1.6 & 1.5 & 1.3 & 0.14 & 0.325 \\
\hline Total chewing time, min/day & 550 & 608 & 569 & 599 & 21.65 & 0.233 \\
\hline Number of daily bolus, n/day & 489 & 518 & 461 & 440 & 34 & 0.423 \\
\hline Number of daily chews, $n \times 1000 /$ day & 32.4 & 31.0 & 31.5 & 29.9 & 1.74 & 0.786 \\
\hline Number of chews per bolus, n/bolus & 67 & 61 & 69 & 69 & 4 & 0.395 \\
\hline Chewing time per bolus, min/bolus & 0.7 & 0.7 & 0.7 & 0.8 & 0.04 & 0.305 \\
\hline
\end{tabular}

DM - dry matter; NDF - neutral detergent fibre; SEM - standard error of the mean; ${ }^{\text {ab }}$ - means with different superscripts in the same row are statistically different (Tukey's test, $P<0.05$ ) 
Table 5. Effect of diet supplementation with crude brown propolis, propolis ethanol extract and sodic monensin on morphometric measurements of lambs

\begin{tabular}{|c|c|c|c|c|c|c|}
\hline \multirow[b]{2}{*}{ Indices } & \multicolumn{4}{|c|}{ Treatments } & \multirow{2}{*}{ SEM } & \multirow{2}{*}{$\begin{array}{l}P \text { - } \\
\text { value }\end{array}$} \\
\hline & control & $\begin{array}{l}\text { crude } \\
\text { propolis }\end{array}$ & $\begin{array}{l}\text { propolis } \\
\text { extract }\end{array}$ & $\begin{array}{l}\text { sodic } \\
\text { monensin }\end{array}$ & & \\
\hline Body length, cm & 80.0 & 81.6 & 81.7 & 81.3 & 3.24 & 0.981 \\
\hline Height at withers, $\mathrm{cm}$ & n 66.1 & 62.2 & 59.4 & 59.1 & 1.91 & 0.065 \\
\hline Height at rump, $\mathrm{cm}$ & 58.7 & 63.2 & 59.0 & 61.5 & 1.62 & 0.202 \\
\hline Width at rump, cm & 23.1 & 22.5 & 22.7 & 24.1 & 0.69 & 0.398 \\
\hline Chest girth, cm & 82.7 & 78.9 & 83.0 & 80.4 & 1.97 & 0.425 \\
\hline $\begin{array}{l}\text { Body compactness, } \\
\mathrm{kg} / \mathrm{cm}\end{array}$ & 0.4 & 0.4 & 0.4 & 0.4 & 0.01 & 0.533 \\
\hline $\begin{array}{l}\text { Internal carcass } \\
\text { length, } \mathrm{cm}\end{array}$ & $56.7^{\circ}$ & $61.7^{\mathrm{a}}$ & $58.6^{\mathrm{bc}}$ & $59.6^{\mathrm{ab}}$ & 0.72 & 0.001 \\
\hline $\begin{array}{l}\text { External carcass } \\
\text { length, } \mathrm{cm}\end{array}$ & $75.5^{\mathrm{b}}$ & $83.0^{\mathrm{a}}$ & $79.4^{\mathrm{ab}}$ & $77.1^{\mathrm{ab}}$ & 1.19 & 0.001 \\
\hline Rump perimeter, cm & 30.0 & 31.1 & 29.9 & 29.0 & 0.70 & 0.232 \\
\hline Thorax depth, cm & $20.5^{b}$ & $21.8^{a}$ & $20.0^{\mathrm{b}}$ & $21.2^{\mathrm{a}}$ & 0.25 & 0.001 \\
\hline $\begin{array}{l}\text { Carcass compact- } \\
\text { ness, } \mathrm{kg} / \mathrm{cm}\end{array}$ & 0.3 & 0.3 & 0.3 & 0.3 & 0.01 & 0.112 \\
\hline
\end{tabular}

SEM - standard error of the mean; ab - means with different superscripts in the same row are statistically different (Tukey's test, $P<0.05$ )

Table 6. Effect of diet supplementation with crude brown propolis, propolis ethanol extract and sodic monensin on carcass and meat traits of lambs

\begin{tabular}{|c|c|c|c|c|c|c|}
\hline \multirow[b]{2}{*}{ Indices } & \multicolumn{4}{|c|}{ Treatments } & \multirow{2}{*}{ SEM } & \multirow{2}{*}{$\begin{array}{l}P \text { - } \\
\text { value }\end{array}$} \\
\hline & control & $\begin{array}{l}\text { crude } \\
\text { propolis }\end{array}$ & $\begin{array}{l}\text { propolis } \\
\text { extract }\end{array}$ & $\begin{array}{l}\text { sodic } \\
\text { monensin }\end{array}$ & & \\
\hline Slaughter weight, kg & 34.5 & 36.9 & 35.6 & 34.4 & 1.33 & 0.402 \\
\hline $\begin{array}{l}\text { Hot carcass weight, } \\
\mathrm{kg}\end{array}$ & 16.6 & 17.4 & 16.4 & 15.4 & 0.59 & 0.164 \\
\hline $\begin{array}{l}\text { Cold carcass weight, } \\
\mathrm{kg}\end{array}$ & 15.2 & 15.9 & 15.0 & 14.1 & 0.55 & 0.186 \\
\hline Cooling losses, g/kg & 87.4 & 88.6 & 85.3 & 84.9 & 1.6 & 0.361 \\
\hline Hot dressing, g/kg & $482.1^{\mathrm{a}}$ & $473.1^{\mathrm{ab}}$ & $460.3^{\mathrm{bc}}$ & $448.3^{c}$ & 3.7 & 0.001 \\
\hline Cold dressing, g/kg & $440.0^{a}$ & $431.2^{\mathrm{ab}}$ & $421.0^{\mathrm{bc}}$ & $410.2^{c}$ & 3.3 & 0.001 \\
\hline $\begin{array}{l}\text { Longissimus muscle } \\
\text { area, } \mathrm{cm}^{2}\end{array}$ & 13.83 & 314.91 & 14.51 & 13.38 & 0.47 & 0.133 \\
\hline $\begin{array}{l}\text { Subcutaneous fat } \\
\text { thickness, } \mathrm{mm}\end{array}$ & $8.8^{a}$ & $5.4^{b}$ & $6.1^{\mathrm{ab}}$ & $6.4^{\mathrm{ab}}$ & 0.71 & 0.021 \\
\hline Leg, g/kg & 325.9 & 318.9 & 326.2 & 313.2 & 5.1 & 0.241 \\
\hline Shoulder, g/kg & 181.6 & 181.7 & 180.9 & 177.4 & 3.8 & 0.847 \\
\hline Ribs, g/kg & 184.8 & 187.5 & 186.2 & 197.5 & 4.9 & 0.285 \\
\hline Loin, g/kg & 149.7 & 149.6 & 147.6 & 149.7 & 3.5 & 0.963 \\
\hline Rack, g/kg & 91.7 & 90.5 & 92.9 & 93.6 & 3.6 & 0.935 \\
\hline Neck, g/kg & 66.3 & 71.8 & 66.2 & 68.6 & 1.9 & 0.165 \\
\hline $\begin{array}{l}\text { Muscle, } g / g \text { fresh } \\
\text { weight }\end{array}$ & 0.49 & 0.49 & 0.48 & 0.50 & 0.03 & 0.977 \\
\hline Fat, g/g fresh weight & 0.27 & 0.31 & 0.34 & 0.32 & 0.03 & 0.433 \\
\hline $\begin{array}{l}\text { Bone, } g / g \text { fresh } \\
\text { weight }\end{array}$ & 0.24 & 0.20 & 0.18 & 0.18 & 0.02 & 0.201 \\
\hline
\end{tabular}

SEM - standard error of the mean; ${ }^{\text {ab }}$ - means with different superscripts in the same row are statistically different (Tukey's test, $P<0.05$ )
Slaughter weight $(\mathrm{SW})$ did not differ $(P>0.05)$ among lambs fed different dietary additives (average BW $35.3 \mathrm{~kg}$, Table 6). HD and CD of lambs fed diet with crude propolis or alcoholic extract were higher than of that receiving diet supplemented with sodic monensin. Subcutaneous fat thickness (SFT) was higher $(P<0.05)$ in animals fed control diet compared to lambs fed diet with crude propolis. Other meat traits $(\mathrm{HCW}=16.5 \mathrm{~kg}, \mathrm{CCW}=15.0 \mathrm{~kg}, \mathrm{CL}=$ $88.6 \mathrm{~g} / \mathrm{kg}$ and $\left.\mathrm{LMA}=14.2 \mathrm{~cm}^{2}\right)$ were not affected $(P>0.05)$ by the diets (Table 6).

The proportion of dissected carcass tissues was also similar $(P>0.05)$ between the treatments (muscle $=0.49$, fat $=0.31$ and bone $=0.20 \mathrm{~g} / \mathrm{g}$ fresh weight), similarly was the yield of the evaluated cuts $($ leg $=321.0$, shoulder $=180.4$, rib $=189.0$, loin $=149.2$, rack $=92.2$ and neck $=68.2 \mathrm{~g} / \mathrm{kg}$ of carcass) (Table 6).

Regarding the fatty acid profile of the meat, 11 fatty acids were identified (Table 7). Lauric acid (C12:0) content was decreased in meat from animals fed diet with propolis extract $(P<0.05)$. So there was a decrease effect $(P<0.05)$ of propolis on saturated fatty acid (SFA) content and an increase effect $(P<0.05)$ on unsaturated fatty acid (UFA) content in lamb meat in comparison to treatment without additive (Table 7).

Table 7. Effect of diet supplementation with crude brown propolis, propolis ethanol extract and sodic monensin on fatty acid profile $\mathrm{g} / \mathrm{kg}$ of fatty acid methyl esters) in Longissimus dorsi muscle of lambs

\begin{tabular}{|c|c|c|c|c|c|c|}
\hline \multirow[b]{2}{*}{ Indices } & \multicolumn{4}{|c|}{ Treatments } & \multirow{2}{*}{ SEM } & \multirow{2}{*}{$\begin{array}{l}P \text { - } \\
\text { value }\end{array}$} \\
\hline & control & $\begin{array}{l}\text { crude } \\
\text { propolis }\end{array}$ & $\begin{array}{l}\text { propolis } \\
\text { extract }\end{array}$ & $\begin{array}{l}\text { sodic } \\
\text { monensin }\end{array}$ & & \\
\hline C10:0 & 2.1 & 2.0 & 1.4 & 1.4 & 0.30 & 0.249 \\
\hline C12:0 & $2.1^{\mathrm{a}}$ & $1.2^{\mathrm{ab}}$ & $1.1^{\mathrm{b}}$ & $1.6^{\mathrm{ab}}$ & 0,24 & 0.045 \\
\hline C14:0 & 36.1 & 27.7 & 28.2 & 35.4 & 2.78 & 0.095 \\
\hline C15:0 & 4.0 & 2.9 & 3.3 & 4.4 & 0.43 & 0.112 \\
\hline C16:0 & 316.7 & 298.8 & 292.0 & 302.2 & 11.23 & 0.436 \\
\hline C16:1 & 20.8 & 19.3 & 16.4 & 17.8 & 2.20 & 0.531 \\
\hline C17:0 & 10.7 & 9.3 & 9.9 & 11.2 & 0.81 & 0.469 \\
\hline C17:1 & 5.1 & 4.8 & 4.3 & 5.3 & 0.29 & 0.120 \\
\hline C18:0 & 186.9 & 180.6 & 190.0 & 184.6 & 8.68 & 0.929 \\
\hline C18:1 cis-9 & 395.1 & 431.0 & 432.0 & 415.2 & 12.73 & 0.211 \\
\hline C18:2 n-6 & 20.4 & 22.3 & 21.6 & 20.8 & 1.45 & 0.789 \\
\hline SFA & $537.2^{\mathrm{a}}$ & $503.9^{b}$ & $506.1^{b}$ & $518.4^{\mathrm{ab}}$ & 3.50 & 0.033 \\
\hline UFA & $441.4^{b}$ & $477.4^{\mathrm{a}}$ & $474.3^{a}$ & $459.1^{\mathrm{ab}}$ & 5.07 & 0.028 \\
\hline
\end{tabular}

SEM - standard error of the mean; SFA - saturated fatty acids; UFA - unsaturated fatty acids; ${ }^{\text {ab }}$ - means with different superscripts in the same row are statistically different (Tukey's test, $P<0.05$ )

\section{Discussion}

Sodic monensin had negative effect on DM and NDF intake as compared to crude propolis treatment, but without the influence on feed conversion ratio. 
However, animals fed crude propolis treatment intake more (568 g NDF/day and $1185 \mathrm{~g} \mathrm{DM} /$ day) than those fed sodic monensin. According to Oliveira et al. (2007) and Gonzalez-Momita et al. (2009) the supply of monensin to the finishing lamb diet promoted a decrease in nutrient intake, but did not alter the digestibility.

The reduction in DM intake when brown propolis alcoholic extract was added into the lamb diet was not observed. However, Ítavo et al. (2011b) showed that brown propolis alcoholic extract reduced DM intake in finishing lambs. Lambs fed diet with crude and alcoholic extract propolis showed high DM and NDF intakes. It may be related to phenol and flavonoid contents in this additives. The flavonoid content in propolis extract, which displays bactericidal activity on the ruminal microorganisms (Aguiar et al., 2013), is the possible cause of increased feed intake. According to de Paula et al. (2016) phenolic compounds intra-ruminally dosed at 16.9 and $33.9 \mathrm{mg} / \mathrm{d}$ increased ruminal acetate molar proportion in buffaloes averaging $543.97 \pm 32.19 \mathrm{~kg}$ of body weight fitted with rumen cannulas, and also reduced ruminal Entodinium population. Phenolic compounds present in propolis extract may improve ruminal fermentation consequently influencing nutrient intake (de Paula et al., 2016).

Feed conversion ratio was not influenced by treatments. Improvement in feed conversion ratio was however observed by Ítavo et al. (2011b) in lambs fed brown propolis alcoholic extract, and by Heydari et al. (2008) using monensin (30 $\mathrm{mg} / \mathrm{kg} \mathrm{DM})$ in the diet. The likely difference between the results can be related to the different phenol and flavonoids contents in additives.

The time spent by animals on different behavioural activities was not affected by the use of different additives. Inclusion of $20.2 \mathrm{mg}$ of flavonoids from brown propolis alcoholic extract into the diet, did not affect the sheep ingestive behaviour (Ítavo et al., 2011a), which is consistent with results obtained in this study (flavonoids dose was $18.98 \mathrm{mg}$ ). However, according to Ítavo et al., (2011a) high inclusion of flavonoids reduced rumination time and increased rest time of feedlot lambs, which can be a negative effect related to the possible toxicity of flavonoids.

In addition, the amount of alcohol ingested from the brown propolis alcoholic extract could also interfere with DMI, since Gomes et al. (2017) found DM degradability of $678.55 \mathrm{~g} / \mathrm{kg}$ which decreased exponentially as a function of the increase in dose $(y=678.55 \times$ dose -0.271 ; Table 2$)$, obtaining the lowest value $(303.61 \mathrm{~g} / \mathrm{kg})$ after a pure ethanol dose of $20 \mathrm{ml} / \mathrm{kg}$ DM. The decrease of $\mathrm{FR}_{\mathrm{DM}}$ of monensin treatment probably is related to lower values of DM intake.

The fibre content in the diet and the particle size are the main factors that affect rumination time. Diets in the present experiment were formulated to have the same fibre content and physical form, which explains the similarity in rumination efficiency between the treatments. Likewise, the total chewing time, number of daily bolus, number of ruminating chews and time of chewing per bolus were not affected by different treatments.

The morphometric measurements (BL, HW, HR, WR, and CG) were not affected by the dietary treatments. This equality is probably caused by the similarity in the animal genetic pattern and BW. According to Landim et al. (2007), BW is associated with in vivo morphological measurements such as $\mathrm{BL}\left(\mathrm{r}^{2}=\right.$ $0.42)$ and $C G\left(r^{2}=0.72\right)$.

In general, in vivo morphological measures, such as (BL) and (CG) indicated by Landim et al. (2007), were positively correlated with BW of animals. Most of the morphometric measurements of the carcasses (ICL, ECL, RP and CC) were not affected by the additives used. This is probably associated with animal homogeneity and SW of the lambs.

Carcass measurements (SW, HCW, CCW, CL and LMA) were not affected by the dietary treatments and may result from similarities in animal performance in feedlot. Ítavo et al. (2009) found that the use of brown propolis alcoholic extract reduced SW in lambs. This effect was not visible in the present study because of the different flavonoid dosage used in each assay.

Our results indicate that good quality carcasses were produced in this assay (mean values: $\mathrm{HCW}=$ 16.5 and $\mathrm{CCW}=15.1 \mathrm{~kg}$ ). They are in agreement with findings of Moreno et al. (2010) who stated that good quality carcasses are characterized by $\mathrm{HCW}$ equal or greater than $14.3 \mathrm{~kg}$ and $\mathrm{CCW}$ equal or greater than $13.8 \mathrm{~kg}$. Hot and cold dressings were lesser in animals receiving propolis extract or sodic monensin when compared to the control group. Crude propolis did not present a negative effect on dresse. Feed additives had no effect on yield of cuts.

Among the identified fatty acids, oleic acid (C18:1 cis-9) was the UFA that mostly contributed to the composition of the lipid profile. Palmitic (C16:0) and stearic (C18:0) fatty acids appeared in the highest proportion among SFAs, more than $90 \%$ of the chromatogram total area. Stands out the presence of monounsaturated fatty acids in lamb meat when included in the human diet can decrease plasma concentration of low density lipoproteins (LDL).

The lowest concentration of lauric acid (C12:0) after the addition of propolis extract into diet may 
be related to the effect of the additive on ruminal microbial activity. Aguiar et al. (2013) stated that propolis possesses antimicrobial activity against rumen bacteria in vitro and in some studies was found that propolis can alter rumen microbial fermentation in vitro and in vivo. According to Heimbach et al. (2016), green and brown propolis have negative effects on growth of Gram-positive bacteria, such as Butyrivibrio species. The phenolic compounds from the propolis may act on these bacterial species during the biohydrogenation process. It was also found that propolis decreases methane formation in the rumen and at the same time enhances the usage of hydrogen to produce short-chain fatty acids production (Morsy et al., 2015); this also may affect the biohydrogenation process of unsaturated fatty acids in the rumen. According to Aguiar et al. (2014) changes in fatty acids composition can be attributed to the rumen fermentation process, and thus, to the lipid metabolism.

\section{Conclusions}

The use of brown propolis, crude or alcoholic extract, affected the meat quality, which may be reflected in the human health and can confirm the use of propolis as nutritional additive for ruminants.

The obtained results showed that propolis addition into lambs diet can influence morphometric measurements of lambs (e.g., carcass length), carcass trait (e.g., subcutaneous fat thickness) as well as meat quality (fatty acids profile); however there are stated differences between different forms of brown propolis (crude form vs ethanol extract). As the brown propolis supplementation affected the meat quality in this study, the use of propolis as nutritional additive for ruminants can be suggested, which may be important for the human nutrition.

\section{Acknowledgements}

The present study was funded by the Conselho Nacional de Desenvolvimento Científico e Tecnológico - CNPq (proc.: 477897/2008-8); and carried out with the support of the Coordenação de Aperfeiçoamento de Pessoal de Nível Superior CAPES (Financing Code 001).

\section{References}

Aquiar S.C., Cottica S.M., Boeing J.S., Samensari R.B., Santos G.T., Visentainer J.V., Zeoula L.M., 2014. Effect of feeding phenolic compounds from propolis extracts to dairy cows on milk production, milk fatty acid composition, and the antioxidant capacity of milk. Anim. Feed Sci. Technol. 193, 148-154, https:// doi.org/10.1016/j.anifeedsci.2014.04.006
Aguiar S.C., Zeoula L.M., Franco S.L., Peres L.P., Arcuri P.B., Forano E., 2013. Antimicrobial activity of Brazilian propolis extracts against rumen bacteria in vitro. World J. Microbiol. Biotechnol. 29, 1951-1959, https://doi.org/10.1007/s11274013-1361-x

AOAC International, 2000. Official Methods of Analysis of AOAC International. $17^{\text {th }}$ Edition. Gaithersburg, MD (USA)

Choi Y.M., Noh D.O., Cho S.Y., Suh H.J., Kim K.M., Kim J.M., 2006. Antioxidant and antimicrobial activities of propolis from several regions of Korea. LWT - Food Sci. Technol. 39, 756-761, https://doi.org/10.1016/j.lwt.2005.05.015

de Paula E.M., Samensari R.B., Machado E., Pereira L.M., Maia F.J., Yoshimura E.H., Franzolin R., Faciola A.P., Zeoula L.M., 2016. Effects of phenolic compounds on ruminal protozoa population, ruminal fermentation, and digestion in water buffaloes. Livest. Sci. 185, 136-141, https://doi.org/10.1016/j. livsci.2016.01.021

Funari C.S., Ferro V.O., 2006. Propolis analysis. Ciencia Tecnol. Aliment. 26, 171-178, https://doi.org/10.1590/S010120612006000100028

Gomes M.F.F., Ítavo C.C.B.F., Ítavo L.C.V., Leal C.R.B., Silva J.A., Heimbach N.S., Leal E.S., 2017. In vitro fermentation characteristics of ruminant diets using ethanol extract of brown propolis as a nutritional additive. Rev. Bras. Zootecn. 46, 599-605, https://doi.org/10.1590/s1806-92902017000700007

Gomes M.F.F., İtavo C.C.B.F., Leal C.R.B., İtavo L.C.V., Lunas R.C., 2016. In vitro biological activity of brown propolis. Pesqui. Vet. Bras. 36, 279-282, https://doi.org/10.1590/S0100736X2016000400005

Gonzalez-Momita M.L., Kawas J.R., García-Castillo R., GonzalezMorteo C., Aguirre-Ortega J., Hernandez-Vidal G., FimbresDurazo H., Picón-Rubio F.J., Lu C.D., 2009. Nutrient intake, digestibility, mastication and ruminal fermentation of Pelibuey lambs fed finishing diets with ionophore (monensin or lasalocid) and sodium malate. Small Ruminant Res. 83, 1-6, https:// doi.org/10.1016/j.smallrumres.2008.11.008

Heimbach N.S., Ítavo C.C.B.F., Ítavo L.C.V., Franco G.L., Leal C.R.B., Leal E.S., Silva P.C.G., Rezende L.C., Silva J.A., 2014. Residue from extraction of brown propolis in the diet to ruminants: in vitro digestibility and gas production. Arch. Zootecn. 63, 259-267, https://doi.org/10.4321/S0004-05922014000200004

Heimbach N.S., Ítavo C.C.B.F., Leal C.R.B., Ítavo L.C.V., Silva J.A., Silva P.C.G., Rezende L.C., Gomes M.F.F., 2016. Propolis extraction residue like bacterial inhibitor in vitro. Rev. Bras. Saúde Prod. Anim. 17, 65-72, https://doi.org/10.1590/S151999402016000100007

Heydari K.H., Dabiri N., Fayazi J., Roshanfekr H., 2008. Effect of ionophores monensin and lasalocid on performance and carcass characteristics in fattening Arabi lambs. Pak. J. Nutr. 7, 81-84, https://doi.org/10.3923/pjn.2008.81.84

Ítavo C.C.B.F., Morais M.G., Costa C., İtavo L.C.V., Franco G.L., da Silva J.A., Reis F.A., 2011a. Addition of propolis or monensin in the diet: behaviour and productivity of lambs in feedlot. Anim. Feed Sci. Technol. 165, 161-166, https://doi.org/10.1016/j. anifeedsci.2011.02.020

Ítavo C.C.B.F., Morais M.G., Costa C., İtavo L.C.V., Macedo F.A.F., Tomich T.R., 2009. Carcass characteristics, non-components and yield of retail products from lambs in feedlot system receiving diets with propolis or sodic monensin as additive. Rev. Bras. Zootecn. 38, 898-905, https://doi.org/10.1590/S151635982009000500017

Ítavo C.C.B.F., Morais M.G., Ramos C.L., İtavo L.C.V., Tomich T.R., Silva J.A., 2011b. Green propolis extract as additive in the diet for lambs in feedlot. Rev. Bras. Zootecn. 40, 1991-1996, https://doi.org/10.1590/S1516-35982011000900021 
Landim A.V., Mariante A.S., McManus A., Gurgel R., Paiva S.R., 2007. Quantitative carcass characteristics, morphometric measurements and their correlations in different sheep genotypes (in Portuguese: Características quantitativas da carcaça, medidas morfométricas e suas correlações em diferentes genótipos de ovinos). Ciencia Anim. Bras. 8, 665-676

Matthews C., Crispie F., Lewis E., Reid M., O'Toole P.W., Cotter P.D., 2018. The rumen microbiome: a crucial consideration when optimising milk and meat production and nitrogen utilisation efficiency. Gut Microbes, https://doi.org/10.1080/19490976.2 018.1505176

Mertens D.R., 2002. Gravimetric determination of amylase-treated neutral detergent fiber in feeds with refluxing in beaker or crucibles: collaborative study. J. AOAC Int. 85, 1217-1240

Mirzoeva O.K., Grishanin R.N., Calder P.C., 1997. Antimicrobial action of propolis and some of its components: the effects on growth, membrane potential and motility of bacteria. Microbiol. Res. 152, 239-246, https://doi.org/10.1016/S09445013(97)80034-1

Moreno G.M.B., Silva Sobrinho A.G., Leão A.G., Oliveira R.V., Yokoo M.J.I., Sousa Júnior S.C., Perez H.L., 2010. Morphological characteristics in vivo and carcass of lambs finished in feedlot and their correlations. Rev. Bras. Saúde Prod. Anim. 11, 888-902

Morsy A.S., Soltan Y.A., Sallam S.M.A., Kreuzer M., Alencar S.M., Abdalla A.L., 2015. Comparison of the in vitro efficiency of supplementary bee propolis extracts of different origin in enhancing the ruminal degradability of organic matter and mitigating the formation of methane. Anim. Feed Sci. Technol. 199, 51-60, https://doi.org/10.1016/j.anifeedsci.2014.11.004

NRC (National Research Council), 2007. Nutrient Requirements of Small Ruminants: Sheep, Goats, Cervids, and New World Camelids. The National Academies Press. Washington, DC (USA), https://doi.org/10.17226/11654

Oliveira M.V.M., Lana R.P., Eifert E.C., Luz D.F., Pereira J.C., Pérez J.R.O., Vargas Júnior F.M., 2007. Effect of monensin on intake and apparent digestibility of nutrients in sheep fed diets with different crude protein levels. Rev. Bras. Zootecn. 36, 643-651, http://dx.doi.org/10.1590/S151635982007000300018
Osório J.C., de Oliveira N.M., Jardim P.O., Monteiro E.M., 1996a. Meat production in sheep of five genotypes: 2 . Live weight components. Ciencia Rural 26, 471-475, https://doi.org/10.1590/ S0103-84781996000300023

Osório J.C., de Oliveira N.M., Nunes A.P., Pouey J.L., 1996b. Meat production in sheep of five genotypes: 3 . Losses and morphology. Ciencia Rural 26, 477-481, https://doi.org/10.1590/ S0103-84781996000300024

Robertson J.B., Van Soest P.J., 1981. The detergent system of analysis and its application to human foods. In: W.P.T. James, 0 . Theander (Editors). The Analysis of Dietary Fiber in Food. Marcel Dekker Inc. New York, NY (USA), pp. 123-158

Silva J.A., Ítavo C.C.B.F., Ítavo L.C.V., Morais M.G., Franco G.L., Zeoula L.M., Heimbach N.S., 2014. Effects of dietary brown propolis on nutrient intake and digestibility in feedlot lambs. Rev. Bras. Zootecn. 43, 376-381, https://doi.org/10.1590/ S1516-35982014000700006

Soltan Y.A., Hashem N.M., Morsy A.S., El-Azrak K.M., Nour ElDin A., Sallam S.M., 2018. Comparative effects of Moringa oleifera root bark and monensin supplementations on ruminal fermentation, nutrient digestibility and growth performance of growing lambs. Anim. Feed Sci. Technol. 235, 189-201. https://doi.org/10.1016/j.anifeedsci.2017.11.021

Stelzer F.S., Lana R.P., Campos J.M.S., Mancio A.B., Pereira J.C., Lima J.G., 2009. Performance of milking cows fed concentrate at different levels associated or not with propolis. Rev. Bras. Zootecn. 38, 1381-1389, https://doi.org/10.1590/ S1516-35982009000700030

Stradiotti Jr D., Queiroz A.C., Lana R.P., Pacheco C.G., Eifert E.C., Nunes P.M.M., 2004. Effect of the propolis on amino acids deamination and ruminal fermentation. Rev. Bras. Zootecn. 33, 1086-1092, http://dx.doi.org/10.1590/S151635982004000400029

Torres C., Moreno M.Á., Zarazaga M., 2010. Prudent use of antimicrobial agents: Not just for humans. Enferm. Infec. Microbiol. Clin. 28,669-671, https://doi.org/10.1016/j.eimc.2010.09.001 